To Ilo DAvanters

Batratra amb Bettz CUTter

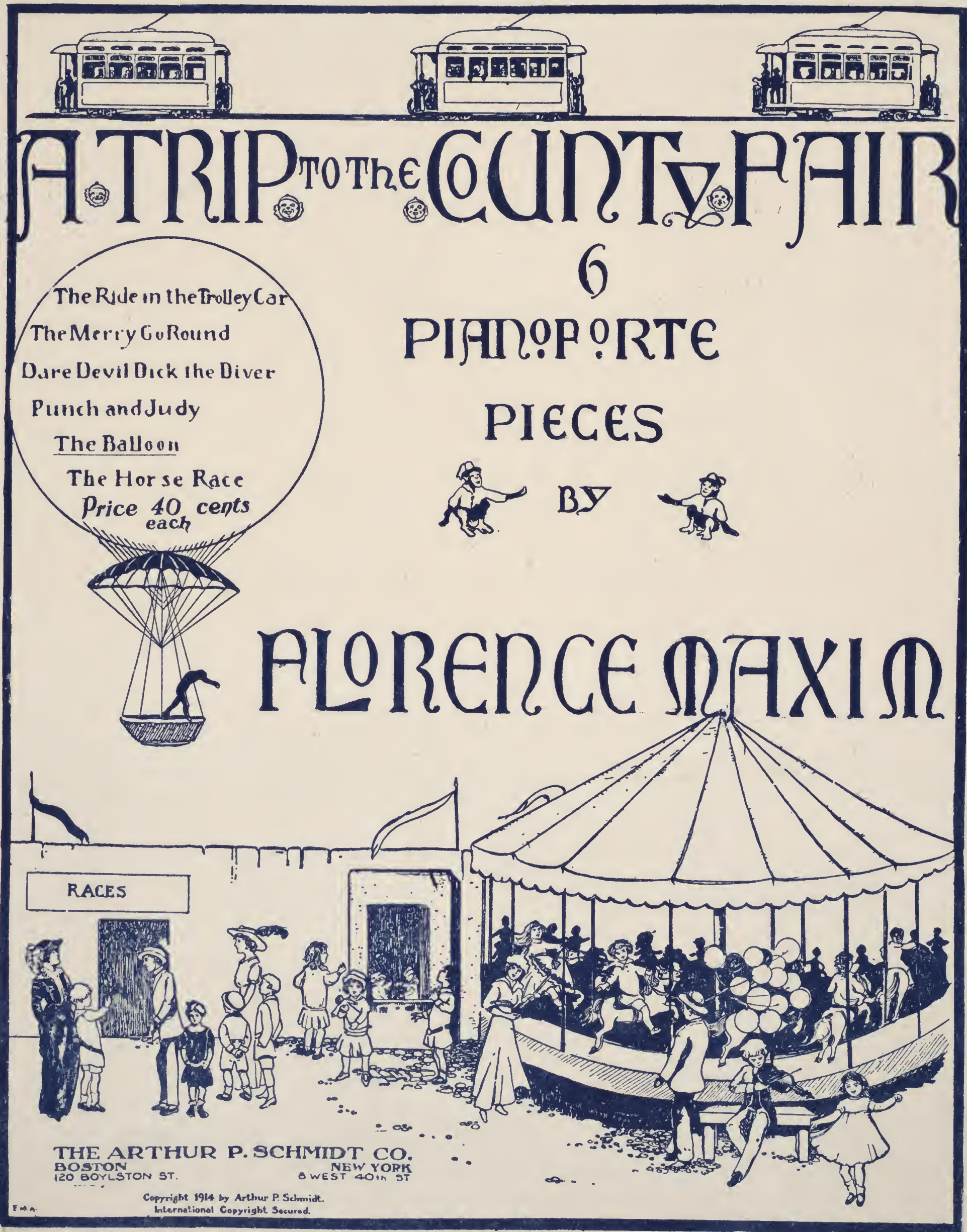




\section{The Balloon}

She's free, she's free, the big balloon!

She's launched on sea of air,

A sea of clear, still atmosphere

For voyage bright and fair.
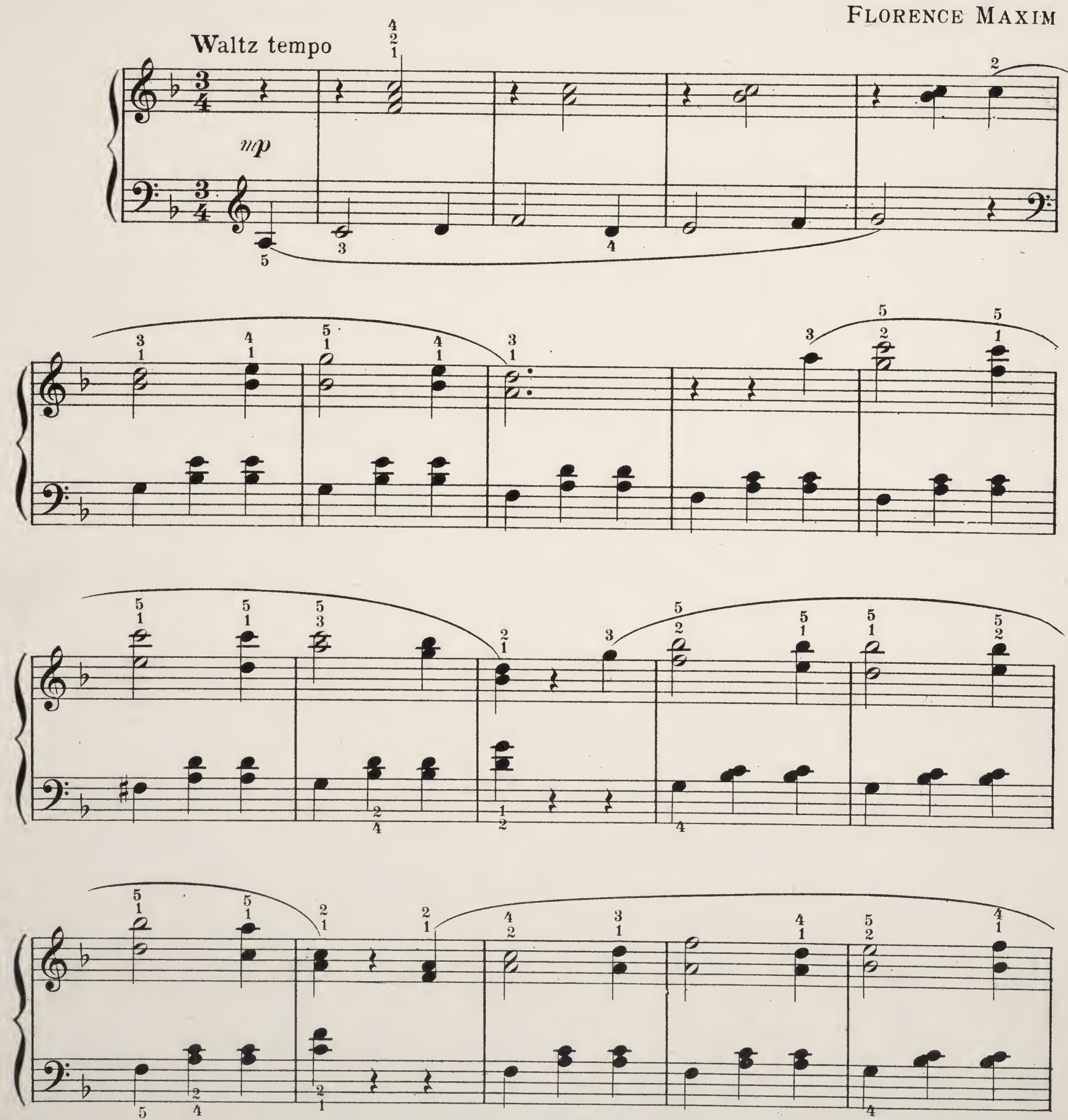

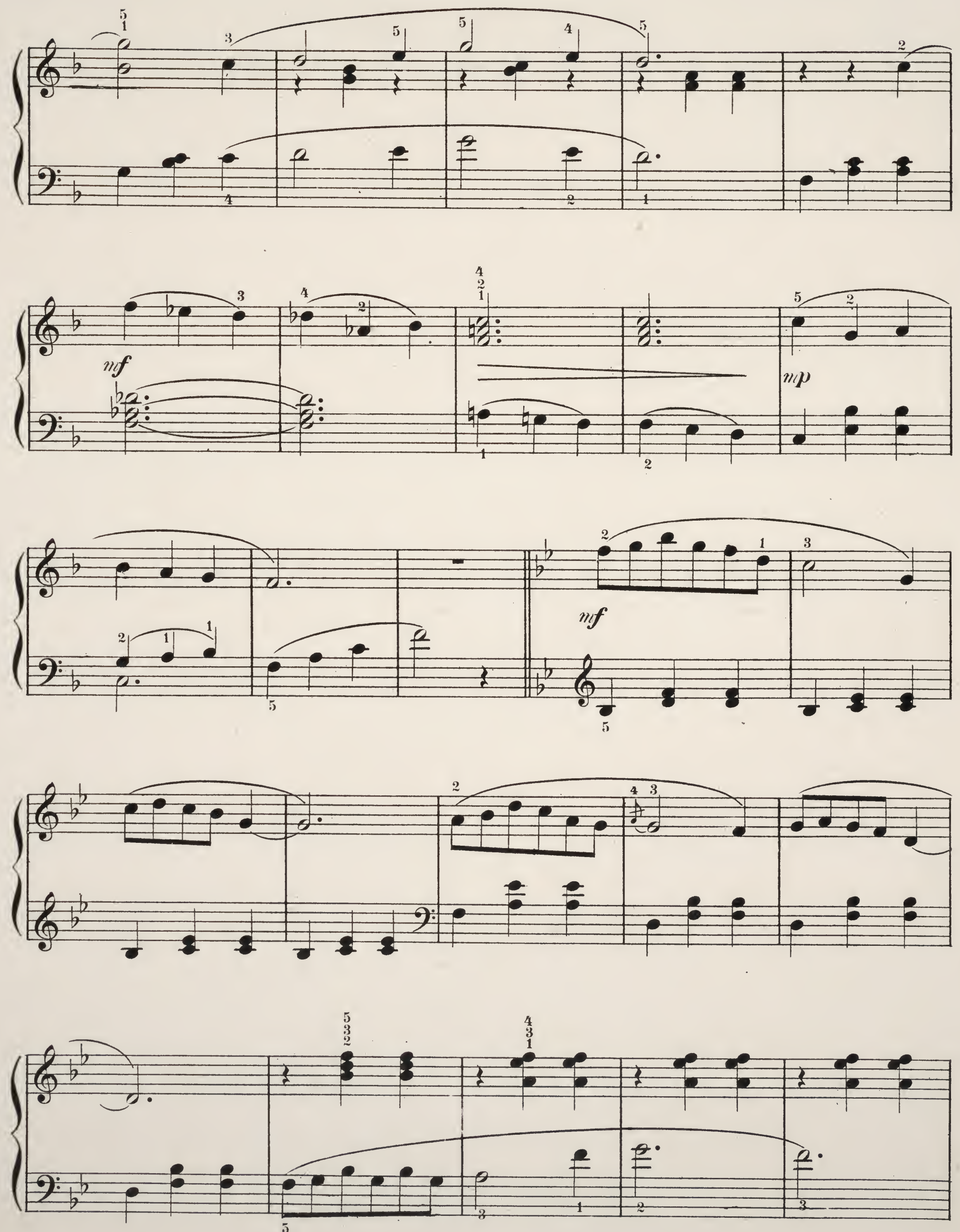
A.P. 8. 10416-4 

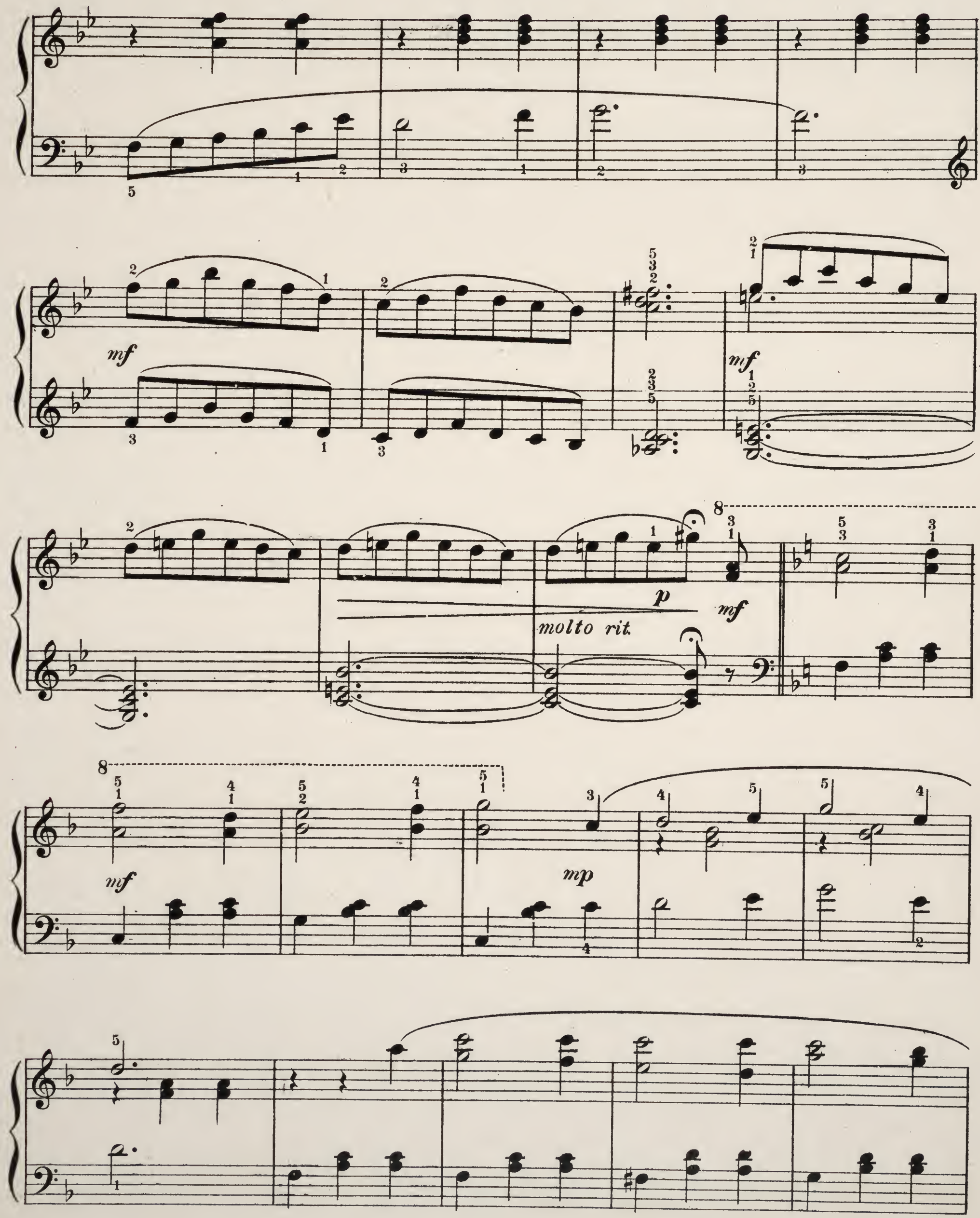

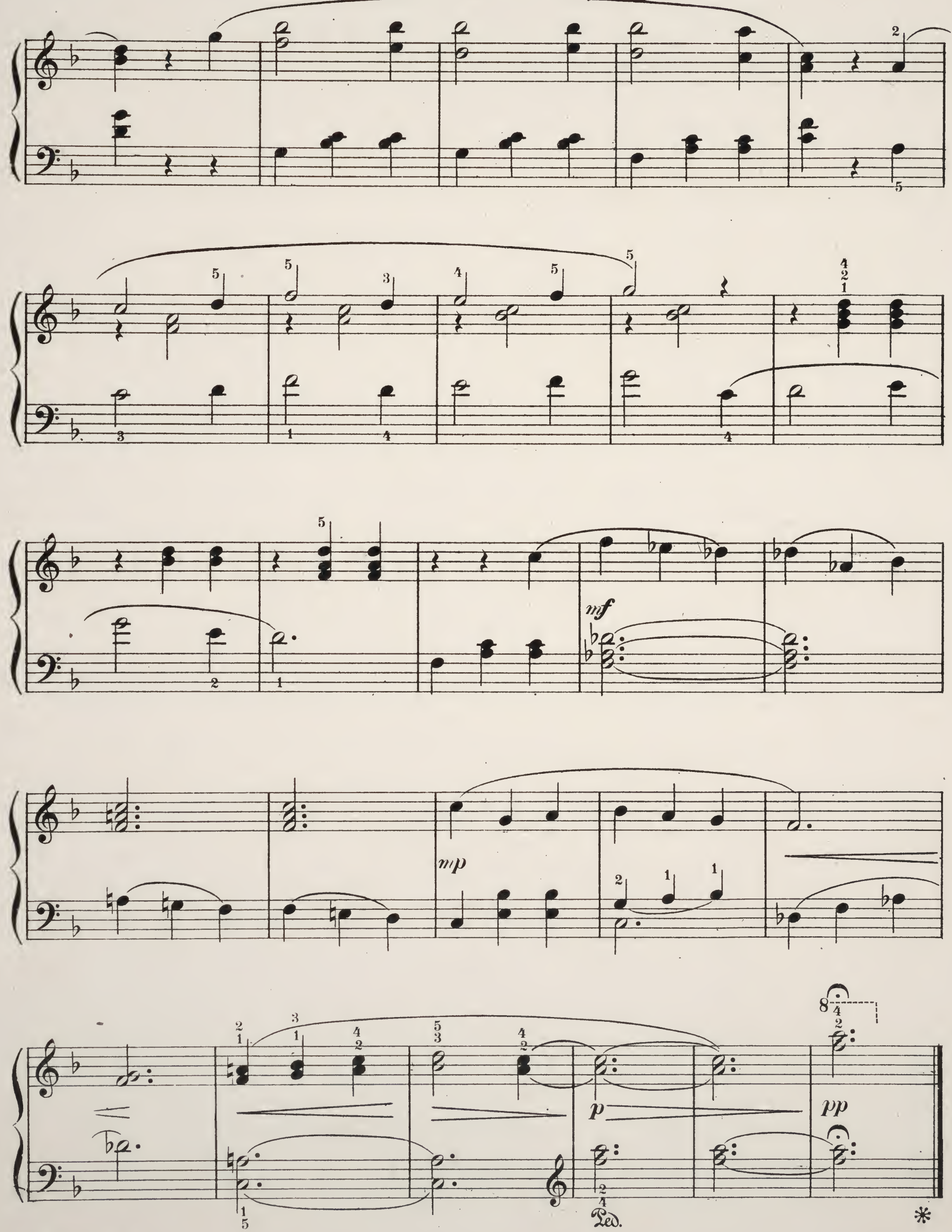
MRS. CROSBY ADAMS

Op. 12. OUTLINE MELODIES.......\$0.40

Op. 14. TONE STORIES ............ .40

Op. 15. CHURCH MUSIC (a Sunday

Group)...............40

The composer has gone back to the very foundation of piano playing, and has furnished music that actual beginners can play with both pleasure and profit.

\section{GENA BRANSCOMBE}

IN A FAIRY GARDEN ...........\$ \$0.50 At the Fairy Ball A Fairy Frolic

The Fairy and the Rose Fairies in a Ring

\section{CORNELIUS GURLITT}

Op. 197. FIRESIDE FANCIES......\$0.60 12 Little Tone Pictures on Five Notes:

(Schmidt's Educational Series No. 50)

Many varieties of rhythm occur in these little pieces, and each hand is treated independently. Gurlitt shows what can be accomplished with the hand in a stationary position over five notes.

MUSICAL SKETCH BOOK.........\$0.75 A selection of favorite pieces, including $V i e n-$ nese $W$ aliz, Maypole Dance, Always Merry, etc.

(Schmidt's Educational Series No. 11)

\section{JOHANN E. HUMMEL}

Op. 486. THE TREASURE BOX \$0.75

12 Favorite Compositions:

Soldier's Lay The Rose Festival

Margaret's Doll

At the Fair

In Graceful' Rhythm

(Minuet)

(Waltz)

Wanderer's Evening Song

The Little Minstrel

The Young Volunteer 'The Hunter's Call

Violet at the Brook Mountain Greeting The Bubbling Spring

\section{R. KRENTZLIN}

Op. 19. VILLAGE SGENES.......\$0.75

A Village Holiday The Cuckoo Calls

Perversity Playing Soldiers

Dance in the Meadow Golden Sunset

(Schmidi's Educational Series No. 59)

\section{FRANK LYNES}

Op. 28. EIGHT FAIRY TALES FOR MUSICAI, CHILDREN............\$

Cinderella's Wedding Little Bo-Peep's March

Slu mber Song

The Dancing Bear

Darby and Joan

Curly Lock's Waltz

Cock Robin's Funeral

See-Saw, Margery

Daw

Jack and Jill Polka

Op. 47. A PLEASANT BEGINNING AND OTHER TUNES FOR LITTLE FINGERS IN ALL THE MAJOR AND MINOR 'KE YS.

(Schmidt's Educational Series No. 19) $\$ 0.75$

The addition of rhymes makes these pieces articularly suitable for young players.

Pieces in all the keys are included.

\section{FLORENGE MAXIM}

THE MUSIC LADDER .......... $\ldots$. \$0.75

16 Easiest Tunes and Rhymes.

The presentation of several versions of the same tune will enable the teacher to select from an abundance of material that which is best suited to the requirements of the pupil.

\section{THE PUPILS' LIBRARY}

FIRST SERIES. Two Books. Each.....\$0.60

35 Easiest Pieces.

(Schmidt's Educational Series No. 48a-b)

The aim has been to create a genuine love of music by providing selections for the player's recreation, and for the delight of his friends. At the same time the books form an admirable series of teaching pieces to be used in conjunction with any pianoforte method.

\section{G. P. RITTER}

FIRST AMUSEMENTS

.$\$ 0.75$

Twolve Pieces on Five Notes.

(Schmidt's Educational Series No. 27)

Contains the well-known favorites The Echo,

Happy Child, First Waltz, etc.

\section{WARREN STOREY SMITH}

Op. 15. EFFORT AND PASTIME Book

24 Melodious Pieces in Ail Keys.

(Schmidt's Educational Series No 38a-b)

In use at the Faelten Pianoforte School, Boston.

\section{ANICE TERHUNE}

THE CHILDREN'S KALEIDOSCOPE . .\$0.60

16 Easy Pieces with Rhymes.

(Schmidt's Educational Series No, 99)

Attractive numbers, with words, for the youngest players.

\section{MABEL MADISON WATSON}

FIRST VISITS TO TUNELAND......\$0.75

A Collection of Rhymes and Tunes to

teach the notes up and down from Mid-

dle C.

A SECOND TRIP TO TUNELAND

More Rhymes and Tunes for Little Players.

TWELVE MAGIC KEYS TO TUNE

LAND .................................

LITTLE TALES FROM TUNELAND... .75

34 Simple Tunes with Rhymes.

SCENES FROM TUNELAND.

Six Little Pieces on Five Notes.

"Miss Watson has done much towards helping to make music an interesting and greater reality for children."-Ethel Syforú in The New England Magazine.

\section{PIANOFORTE DUETS} MRS_CROSBY ADAMS

Op. 13. FOUR DUETS FOR TWO BEGINNERS.

GINNERS.............
Boatman's Tune

The Nodding Grass-Star A Voyage

FLORENGE NEWELL BARBOUR

RAMBLES IN MUSIC-LAND .......\$0.75

First Duets for Pupil and Teacher.

(Schmidt's Educational Series No. 105)

The Beginning of the Twilight Hour

Journey

A Little Song

Onward We Go

(Romance)

(March)

The Chase

Among the Fairies (Waltz)

The part for pupil and teacher alternates between treble and bass throughout the set

\section{CHARLES DENNÉE}

Op. 18. TUIE GHILDREN'S FESTIVAL..\$0.75 10 Easy Duets on Five Notes.

(Schmidt's Educational Series No. 6)

Of unusual melodic interest and contain much variety in style and rhythm. The pupil's part alternates between primo and secondo.

CORNELIUS GURLITT

Op. 178. TENDER BLOSSOMS...... \$0.75 20 Easy Duets.

(Schmidt's Educational Series No. $35 a-b$ )

Primo and secondo parts are written in a melodious vein, and both are interesting and of equal degree of difficulty.

\section{THE PUPILS' DUET ALBUM}

FIRST SERIES. Book I. ......... \$0.60 16 Duets by Dennee, Foote, Franke, Gurlitt,

Lynes, Orth, Sartorio, Schytte and others.

(Schmidt's Educational Series No. 46a-b)

ARNOLDO SARTORIO

Op. 400. PICTURES FROM YOUTH . $\$ 0.60$ 12 Melodious Duets.

Schmidt's Educational Series No. 58a-b)

Excellent for the pupil who has gained slight independence in four-hand playing and is ready to take up a Primo that is not strictly the same for both hands throughout

PIANOFORTE, SIX HANDS GLOVER LEAVES

A Collection of Favorite Pleces for PIANOFORTE, SIX HANDS Arranged by
EDMUND PARLOW

(Schmidt's Educational Series No. 118a) FRANK LYNES, Op. 14, No. 3 . The Hunter's Song. CORN. GURLITT, 362 , No.1. Soldiers Are Cominn. March. GĚZA HOR VX̌TT, Op. 94, No. 3. The Acrobat. A. FOERSTER, Op. 138, No.2. At the Dancing Master's. Price 75 Cents

\begin{tabular}{l}
\hline FIRST \\
YEAR \\
CLASSICS \\
\hline
\end{tabular}

FIRST

YEAR

\section{$\mathrm{BACH}$}

20 Easiest Compositions by

\section{J. S. BACH}

(Schmidi's Educational Series Nos. 85 and 145.) Price 75 Cents Each and am strongly recommending it to my students for use with their pupils."

\section{FIRST YEAR HANDEL \\ 12 Easy Compositions by \\ G. F. HANDEL}

ed and edited in a masterly manner.

I shall use it in my teaching, (Signed) MARY VENABLE.
Edited by

ARTHUR FOOTE

\section{The ARTHUR P. SCEMADDT CO}

BOSTON,

120 Boylston.St. 